\title{
Cholesterol and Cholesterol Esters in Mycoplasma
}

\author{
By M. ARGAMAN and S. RAZIN \\ Department of Clinical Microbiology, Hebrew University-Hadassah Medical School, \\ Jerusalem, Israel
}

(Received 3 September 1964)

\section{SUMMARY}

Free and esterified cholesterol were determined in the lipid extract of nine parasitic and saprophytic Mycoplasma strains. The saprophytic strains were usually free from esterified cholesterol. Esterified cholesterol was found in the parasitic strains at a ratio of $1: 8$ to $1: 3$ to free cholesterol; in the growth medium the ratio was about $\left.4: 1 .{ }^{[4-14} \mathrm{C}\right]$-cholesterol added to the growth medium was incorporated by all Mycoplasma strains without esterification or any other chemical change. [4-14 $\mathrm{C}]$-cholesteryl oleate was incorporated into the lipid of the parasitic strains and was not hydrolysed to yield free cholesterol. The small amounts of radioactive oleic acid incorporated by several Mycoplasma strains during growth was not detected in the cholesteryl ester fraction. Our results show that under the growth conditions examined, the Mycoplasma organisms tested were unable to esterify cholesterol or hydrolyse cholesteryl esters.

\section{INTRODUCTION}

Most Mycoplasma strains have been found to require cholesterol or closely related sterols for growth (Edward \& Fitzgerald, 1951; Smith \& Lynn, 1958; Rodwell \& Abbot, 1961; Rodwell, 1963; Smith, 1964). Only the saprophytic Mycoplasma laidlawii strains do not have this requirement (Edward \& Freundt, 1956; Razin \& Knight, 1960; Rothblat \& Smith, 1961; Razin \& Cohen, 1963). So far no other group of bacteria is known to require sterols for growth (Razin, 1962). Cholesterol in the growth medium was found to be incorporated in appreciable quantities into the lipid fraction of the Mycoplasma cell (Smith \& Rothblat, 1960; Rothblat \& Smith, 1961; Smith, 1962; Smith, 1963a Rodwell, 1963; Tourtellotte, Jensen, Gander \& Morowitz, 1963). Most of the incorporated cholesterol was found in the cell membrane (Rothblat \& Smith, 1961; Razin, Argaman \& Avigan, 1963). When grown in a cholesterol-deficient medium Mycoplasma mycoides showed severe morphological changes, apparently due to faulty synthesis of cell membrane (Rodwell \& Abbot, 1961). Thus, it is plausible that cholesterol is essential for the integrity and regular functioning of the delicate cell membrane of Mycoplasma (Razin, 1963a). Smith (1963a) suggested that cholesterol fulfils a bifunctional role: maintenance of the structural integrity of the cell membrane, and as a carrier of substrates and metabolic end-products across the cell membrane. To elucidate the role played by cholesterol in the physiology of Mycoplasma, it seemed worth while to investigate the fate of cholesterol incorporated by various Mycoplasma strains. The problems dealt with were: $(a)$ is the incorporated 
cholesterol esterified or metabolized in any way? $(b)$ are Mycoplasma organisms able to incorporate cholesteryl esters from the growth medium? (c) are Mycoplasma organisms able to hydrolyse cholesteryl esters to yield free cholesterol?

\section{METHODS}

Organisms. Mycoplasma mycoides var. mycoides (PG 1), M. mycoides var. capri (PG 3), M. agalactiae (PG 2), M. neurolyticum (PG 28), M. laidlawii strain A (PG 8) and $M$. laidlarwii strain B (PG 9) were obtained from Dr D. G. ff. Edward (The Wellcome Research Laboratories, Beckenham, Kent). A strain of M. gallisepticum named ( $\mathrm{R}$ ) was provided by Mrs Ruth Bernstein (Faculty of Agriculture, The Hebrew University, Rehovoth, Israel). Strain s6 of $\boldsymbol{M}$. gallisepticum was obtained from Dr H. E. Adler (School of Veterinary Medicine, University of California, Davis, U.S.A.). M. laidlawii (oral strain )was isolated in our laboratory from the human oral cavity; this strain was serologically related to $M$. laidlawii strain A (Argaman, unpublished observations).

Growth medium and cultivation of organisms. The organisms were grown in a modified liquid Edward medium (Razin, 1963b) which contained $2 \%$ (v/v) DifcoPPLO serum fraction. The radioactive compounds incorporated into the growth medium included $\left[{ }^{4-14} \mathrm{C}\right]$-cholesterol with a specific activity of $24 \mathrm{mC} / \mathrm{mmole}$; $\left[4^{-14} \mathrm{C}\right]$-cholesteryl oleate with a specific activity of $20 \mathrm{mC} / \mathrm{mmole}$ and $\left[\mathrm{U}^{14} \mathrm{C}\right]$-oleic acid with a specific activity of $94 \mathrm{mc} / \mathrm{mmole}$ (all products obtained from the Radiochemical Centre, Amersham, England). A benzene solution containing $1 \mu \mathrm{C}$ of the radioactive compound was evaporated to dryness under a stream of nitrogen and immediately re-dissolved in a few drops of ethanol. The ethanolic solution was then thoroughly mixed with $20 \mathrm{ml}$. Difco-PPLO serum fraction and added to $1 \mathrm{l}$. of growth medium. Fifty ml. of a young culture of the organisms in Edward medium were inoculated into $500 \mathrm{ml}$. medium in $1 \mathrm{l}$. Roux flasks, which were incubated at $37^{\circ}$ for $24-48 \mathrm{hr}$ in an inclined position to improve aeration. The organisms were harvested by centrifugation at $16,000 \mathrm{~g}$ for $5 \mathrm{~min}$., washed twice in $0 \cdot 25 \mathrm{M}$ $\mathrm{NaCl}$ and the sedimented packed organisms freeze-dried.

Extraction of lipids. Lipids were extracted from the freeze-dried organisms by chloroform + methanol ( $2+1$, by vol.). Extraction was carried out at $60^{\circ}$ for $30 \mathrm{~min}$. under reflux in a nitrogen atmosphere. The extract was separated from the organisms by centrifugation and washed with water according to Folch, Lees \& SloaneStanley (1957). The solvent was then evaporated to dryness by heating under a stream of nitrogen, and the lipid residue freeze-dried and weighed. To test the efficiency of the lipid-extraction procedure the extracted organisms were hydrolysed in $2 \mathrm{~N}-\mathrm{HCl}$ at $90-100^{\circ}$ for $15 \mathrm{hr}$ in sealed ampoules. The hydrolysate was extracted three times with diethyl ether. The solvent was evaporated and radioactivity of the residue determined. Lipids were also extracted from freeze-dried Difco-PPLO serum fraction, and from the other dry constituents of Edward medium for the determination of their cholesterol content. Extraction was carried out by chloroform + methanol as described above. 


\section{Determination of cholesterol and its esters}

Chromatographic separation. Cholesterol and cholesteryl esters in the lipids from the Mycoplasma organisms and in the constituents of the growth medium were separated by thin-layer chromatography (Razin et al. 1963; Avigan, Goodman \& Steinberg, 1963). Chromatoplates were prepared by using a slurry containing $50 \mathrm{ml}$. of a $0.1 \%(\mathrm{w} / \mathrm{v})$ aqueous solution of Rhodamine $6 \mathrm{G}$ and $25 \mathrm{~g}$. silica gel $\mathrm{G}$ (E. Merck A. G., Darmstadt, Germany). The lipid to be chromatographed was dissolved in a small volume of benzene and applied to the plates as bands. Chromatography was carried out at room temperature with developing solvent a mixture of benzene + ethyl acetate $(5+1$, by vol.). Running time was about $1 \mathrm{hr}$, during which the solvent front had advanced $12-15 \mathrm{~cm}$. Cholesterol and cholesteryl ester zones were visible after chromatography under ultraviolet radiation as pinkyellow fluorescent areas on a pale green background. Cholesteryl esters migrated with the solvent front, whereas the $R_{F}$ value of cholesterol was about 0.5.

The same chromatoplates were used for separation of free oleic acid from cholesteryl esters, but the solvent was $n$-hexane + diethyl ether + acetic acid + methanol $(90+20+3+2$, by vol.; Brown \& Johnson, 1962). Oleic acid had a lower $R_{F}$ value than cholesteryl esters.

The zones of cholesterol, cholesteryl esters and oleic acid to be recovered, and the zones in between were scraped off with a spatula into test tubes and the lipids eluted by extracting twice with $2 \mathrm{ml}$. chloroform. Two-thirds of the chloroform extract were taken for radioactivity measurements, while the remaining part was used for the colorimetric determination of cholesterol and itsesters.

The purity of the cholesterol fraction separated on the chromatoplate by benzene tethyl acetate $(5+1$, by vol.) was proved by re-chromatography of this fraction, with benzene + ethyl acetate $(20+1$, by vol.) as solvent (Avigan et al. 1963).

Colorimetric determination of cholesterol. The chloroform from the extracts of free and esterified cholesterol zones of the chromatoplates was evaporated under a stream of nitrogen and the dry material dissolved in glacial acetic acid. The amount of cholesterol in solution was determined by the $\mathrm{FeCl}_{3}$ reaction according to Wycoff \& Parsons (1957). By this colorimetric method the recoveries of chromatographically separated cholesterol and its esters averaged $90 \%$. The nonpolar lipids migrating with the cholesteryl esters had little influence on the results of the $\mathrm{FeCl}_{3}$ reaction. This was proved by saponification of the lipid in the cholesteryl ester zone, re-chromatography and determination of the amount of free cholesterol produced. The liberated cholesterol produced practically the same colour intensity as the chromatographic fraction before saponification.

Radioactivity measurements. The chloroform extracts placed in scintillation vials were evaporated by heating under a stream of air. Seven ml. of $\mathbf{0 \cdot 3} \%(\mathrm{w} / \mathrm{v}) \mathbf{2 , 5 -}$ diphenyloxazole (PPO, scintillation grade) and $0 \cdot 1 \%(w / v)$ 1,4-bis-2-(5-phenyloxazolyl)-benzene (POPOP, scintillation grade, Packard Instrument Co., Inc., Illinois, U.S.A.) in toluene were added to each vial by use of a syringe. ${ }^{14} \mathrm{C}$-counting was done in a liquid scintillation counter model 6012 A (Isotope Developments Limited, Reading, England).

Determination of cholesterol esterase activity. A slight modification of the method described by Smith (1959) was used. Mycoplasma organisms grown in Edward 
medium for 24-48 hr were harvested and washed twice with $0.25 \mathrm{M}-\mathrm{NaCl}$ as above. The washed organisms were suspended in $0.06 \mathrm{M}$-phosphate buffer $(\mathrm{pH} \mathrm{6.5})$ to give cell protein 5-10 mg./ml. The organisms suspension was distributed in $2 \cdot 5 \mathrm{ml}$. quantities into test tubes. Cholesteryl acetate ( 5 or $10 \mu$ moles) dissolved in $0 \cdot 1 \mathrm{ml}$. acetone was injected into the suspension of mycoplasmas. The resulting emulsion was stable for at least $24 \mathrm{hr}$ at $37^{\circ}$ without the aid of an emulsifying agent. Controls without substrate or organisms were run simultaneously. The reaction mixtures and controls were incubated at $37^{\circ}$ and $1.2 \mathrm{ml}$. samples drawn after 5 and $24 \mathrm{hr}$ of incubation. To each sample $4 \mathrm{ml}$. chloroform + methanol $(2+1$, by vol. $)$ were added, well mixed and centrifuged. The lower chloroform phase was separated, evaporated to dryness under nitrogen, the residue dissolved in benzene and chromatographed. Free and esterified cholesterol appearing on the chromatoplate were quantitatively determined as described above.

\section{RESULTS}

\section{Free and esterified cholesterol in Mycoplasma organisms}

Free and esterified cholesterol in lipid extracts of various Mycoplasma strains were separated by thin-layer chromatography. The carotenoid pigments of $M y c o-$ plasma laidlawii migrated with the solvent front. The lipids of all three $M$. laidlawii strains contained less free cholesterol than the lipids of the parasitic strains and were usually free from esterified cholesterol (Table 1). The parasitic strains contained various amounts of cholesteryl esters, usually $\frac{1}{9}-\frac{1}{4}$ of the total cholesterol, except $M$. mycoides var. capri which consistently contained more esterified than free cholesterol.

Table 1. Free and esterified cholesterol in lipid of Mycoplasma

Cholesterol and cholesteryl esters were separated by thin-layer chromatography (Avigan et al. 1963), and determined by the $\mathrm{FeCl}_{3}$ reaction (Wycoff \& Parsons, 1957).

\begin{tabular}{|c|c|c|c|c|c|c|}
\hline \multirow[b]{3}{*}{ Organism } & \multicolumn{6}{|c|}{$\%(w / w)$ of total lipid } \\
\hline & \multicolumn{2}{|c|}{ Total cholesterol } & \multicolumn{2}{|c|}{ Free cholesterol } & \multicolumn{2}{|c|}{ Esterified cholesterol } \\
\hline & Mean & Range & Mean & Range & Mean & Range \\
\hline Mycoplasma agalactiae & $30 \cdot 2$ & $24 \cdot 1-36 \cdot 0$ & $26 \cdot 1$ & $21 \cdot 4-31 \cdot 5$ & $3 \cdot 4$ & $2 \cdot 7-4 \cdot 5$ \\
\hline M. gallisepticum (R) & $19 \cdot 5$ & $13 \cdot 8-23 \cdot 0$ & $14 \cdot 7$ & $13 \cdot 2-16 \cdot 0$ & $3 \cdot 5$ & $0 \cdot 6-7 \cdot 0$ \\
\hline M. gallisepticum (s6) & $21 \cdot 3$ & $16 \cdot 2-23 \cdot 4$ & $16 \cdot 0$ & $14 \cdot 5-18 \cdot 0$ & $5 \cdot 3$ & $2 \cdot 0-6 \cdot 4$ \\
\hline$M$. neurolyticum & $12 \cdot 2$ & $9 \cdot 7-12 \cdot 8$ & $\mathbf{9} \cdot \mathbf{3}$ & $5 \cdot 8-10 \cdot 5$ & $3 \cdot 4$ & $\mathbf{2} \cdot \mathbf{3}-\mathbf{3} \cdot \mathbf{9}$ \\
\hline M. mycoides var. mycoides & $17 \cdot 9$ & $17 \cdot 7-18 \cdot 0$ & $13 \cdot 4$ & $10 \cdot 1-15 \cdot 0$ & $4 \cdot 8$ & $3 \cdot 0-7 \cdot 6$ \\
\hline M. mycoides var. capri & $19 \cdot 7$ & $18 \cdot 1-20 \cdot 8$ & $6 \cdot 2$ & $5 \cdot 0-8 \cdot 1$ & $14 \cdot 4$ & $10 \cdot 0-15 \cdot 8$ \\
\hline M. laidlawii strain A & $\mathbf{2 \cdot 9}$ & $\mathbf{1} \cdot \mathbf{7}-\mathbf{3} \cdot \mathbf{1}$ & $2 \cdot 8$ & $1 \cdot 7-3 \cdot 1$ & $0 \cdot 1$ & $0-0.4$ \\
\hline M. laidlawii strain B & $3 \cdot 5$ & $2 \cdot 2-4 \cdot 6$ & $3 \cdot 4$ & $2 \cdot 2-4 \cdot 6$ & $0 \cdot 1$ & $0-0.4$ \\
\hline M. laidlawii oral strain & $3 \cdot 6$ & $2 \cdot 4-4 \cdot 4$ & $3 \cdot 4$ & $2 \cdot 4-4 \cdot 4$ & $0 \cdot 2$ & $0-0.7$ \\
\hline
\end{tabular}

The appearance of cholesteryl esters in the lipids of Mycoplasma prompted us to examine the amount of free and esterified cholesterol in the growth medium. The only component of Edward medium found to contain appreciable amounts of cholesterol and its esters was the Difco-PPLO serum fraction. In several analyses free cholesterol 90-150 $\mu \mathrm{g}$. and esterified cholesterol 360-600 $\mu \mathrm{g} . / \mathrm{ml}$. were found. In all other ingredients only negligible amounts of cholesterol were present. 


\section{Incorporation of $\left[4^{-14} \mathrm{C}\right]$-cholesterol into the lipids of Mycoplasma}

Radioactive cholesterol added to Edward medium was incorporated by all Mycoplasma strains grown in this medium. Radioactivity appeared almost exclusively in the free-cholesterol fraction of the Mycoplasma lipids (Table 2). No appreciable amount of radioactivity was found in the cholesteryl ester zone. Essentially all radioactivity was removed from the organisms by chloroform + methanol extraction. The radioactivity of the defatted organisms, as determined by hydrolysis and ether extraction, was negligible.

\section{Table 2. Incorporation of $\left[4^{-14} \mathrm{C}\right]$-cholesterol into lipids of Mycoplasma}

The organisms were grown in Edward medium containing $1 \mu \mathrm{C}$ [4-14 $\mathrm{C}$-cholesterol/1. The data given in the table represent typical results obtained in several experiments using different batches of organisms.

\begin{tabular}{|c|c|c|c|c|}
\hline & & Radioactivi & $\mathrm{nts} / \mathrm{min} \times 10^{-}$ & Total \\
\hline Organism & $\begin{array}{l}\text { Quantity } \\
\text { of lipid } \\
\text { examined } \\
\text { (mg.) }\end{array}$ & $\begin{array}{l}\text { Total } \\
\text { lipid }\end{array}$ & $\begin{array}{c}\text { Free } \\
\text { cholesterol } \\
\text { fraction }\end{array}$ & $\begin{array}{c}\text { radioactivity in } \\
\text { cholesterol } \\
\text { fraction } \\
(\%)\end{array}$ \\
\hline Mycoplasma agalactiae & $4 \cdot 2$ & $459 \cdot 0$ & $457 \cdot 3$ & $99 \cdot 6$ \\
\hline M. gallisepticum (R) & $12 \cdot 4$ & $399 \cdot 7$ & $397 \cdot 6$ & $99 \cdot 3$ \\
\hline M. gallisepticum (s6) & $9 \cdot 6$ & $490 \cdot 0$ & $488 \cdot 0$ & $99 \cdot 4$ \\
\hline M. neurolyticum & $10 \cdot 4$ & $489 \cdot 0$ & $487 \cdot 0$ & $99 \cdot 4$ \\
\hline M. mycoides var. mycoides & $12 \cdot 0$ & $686 \cdot 2$ & $683 \cdot 6$ & $99 \cdot 6$ \\
\hline M. mycoides var. capri & $48 \cdot 0$ & $318 \cdot 5$ & $\mathbf{3 1 5} \cdot 0$ & $99 \cdot 0$ \\
\hline M. laidlawii strain A & $11 \cdot 1$ & $263 \cdot 0$ & $261 \cdot 0$ & $99 \cdot 2$ \\
\hline M. laidlawii strain B & $20 \cdot 2$ & $182 \cdot 0$ & $180 \cdot 5$ & $99 \cdot 1$ \\
\hline M. laidlawii oral strain & $21 \cdot 4$ & $232 \cdot 3$ & $231 \cdot 2$ & $99 \cdot 4$ \\
\hline [4-14C]-cholesterol $0 \cdot 1 \mu \mathrm{C}$ & - & $204 \cdot 0$ & $202 \cdot 0$ & $99 \cdot 0$ \\
\hline
\end{tabular}

Table 3. Incorporation of [4-14C]-cholesteryl oleate into lipids of Mycoplasma

The growth medium contained $1 \mu \mathrm{C}$ [4-14 $\mathrm{C}]$-cholesteryl oleate/l.

\begin{tabular}{|c|c|c|c|c|c|}
\hline \multirow[b]{2}{*}{ Organism } & \multirow{2}{*}{$\begin{array}{l}\text { Quantity } \\
\text { of lipid } \\
\text { examined } \\
\text { (mg.) }\end{array}$} & \multicolumn{3}{|c|}{ Radioactivity (counts/min $\times 10^{-3}$ ) } & \multirow{2}{*}{$\begin{array}{c}\text { Total } \\
\text { radioactivity in } \\
\text { cholesteryl } \\
\text { ester fraction } \\
(\%)\end{array}$} \\
\hline & & $\begin{array}{l}\text { Total } \\
\text { lipid }\end{array}$ & $\begin{array}{l}\text { Cholesterol } \\
\text { fraction }\end{array}$ & $\begin{array}{l}\text { Cholesteryl } \\
\text { ester fraction }\end{array}$ & \\
\hline $\begin{array}{l}\text { Mycoplasma } \\
\text { agalactiae }\end{array}$ & $4 \cdot 0$ & $72 \cdot 4$ & 0.7 & $71 \cdot 0$ & $98 \cdot 0$ \\
\hline $\begin{array}{l}\text { M. gallisepticum } \\
(\mathbf{R})\end{array}$ & $6 \cdot 0$ & $107 \cdot 9$ & $0 \cdot 93$ & $106 \cdot 6$ & $98 \cdot 7$ \\
\hline $\begin{array}{l}\text { M. mycoides var. } \\
\text { mycoides }\end{array}$ & $13 \cdot 0$ & $291 \cdot 1$ & $0 \cdot 6$ & $289 \cdot 5$ & $99 \cdot 2$ \\
\hline $\begin{array}{l}\text { M. mycoides var. } \\
\text { capri }\end{array}$ & $13 \cdot 7$ & $153 \cdot 7$ & $1 \cdot 0$ & $152 \cdot 2$ & $99 \cdot 0$ \\
\hline $\begin{array}{l}\text { M. laidlazeii } \\
\text { strain A }\end{array}$ & $11 \cdot 6$ & $4 \cdot 5$ & $\mathbf{0} \cdot \mathbf{3}$ & $\mathbf{3 \cdot 9}$ & $86 \cdot 6$ \\
\hline $\begin{array}{l}\text { M. laidlaweii } \\
\text { strain B }\end{array}$ & $12 \cdot 6$ & $4 \cdot 8$ & 0.0 & 4.7 & $98 \cdot 3$ \\
\hline $\begin{array}{l}\text { M. laidlawii oral } \\
\text { strain }\end{array}$ & $11 \cdot 5$ & $0 \cdot 9$ & $0 \cdot 0$ & 0.5 & $62 \cdot 2$ \\
\hline $\begin{array}{c}{[4-14 \mathrm{C}] \text {-cholesteryl }} \\
\text { oleate, } 0 \cdot 1 \mu \mathrm{C}\end{array}$ & - & $239 \cdot 4$ & $0 \cdot 6$ & $238 \cdot 0$ & $99 \cdot 4$ \\
\hline
\end{tabular}




\section{Incorporation of $\left[4^{-14} \mathrm{C}\right]$-cholesteryl oleate into the lipids of Mycoplasma}

Radioactive cholesteryl oleate, added to the growth medium, was incorporated into the lipids of the parasitic strains; the saprophytic strains incorporated only minute amounts of the radioactive compound. Radioactivity was limited to the cholesteryl ester fraction of the Mycoplasma lipids; no radioactivity was detected in the free-cholesterol fraction (Table 3). This showed the inability of the Mycoplasma strains tested to hydrolyse cholesteryl oleate. Washed suspensions of Mycoplasma mycoides var. mycoides, M. mycoides var. capri, M. gallisepticum (R) and $M$. laidlawii strains were unable to hydrolyse cholesteryl acetate. Extracts of M. gallisepticum strains did not hydrolyse cholesteryl acetate or cholesteryl stearate when tested at several values from $\mathrm{pH} 6.5$ to 9.0 (see Rottem \& Razin, 1964).

Table 4. Incorporation of $\left[\mathrm{U}^{-14} \mathrm{C}\right]$-oleic acid into lipids of Mycoplasma The growth medium contained $1 \mu \mathrm{C}\left[\mathrm{U}-{ }^{14} \mathrm{C}\right]-$ oleic acid/l.

\begin{tabular}{|c|c|c|c|c|c|}
\hline \multirow[b]{3}{*}{ Organism } & \multirow{3}{*}{$\begin{array}{c}\text { Quantity } \\
\text { of lipid } \\
\text { examined } \\
\text { (mg.) }\end{array}$} & \multicolumn{4}{|c|}{ Radioactivity (counts/min) } \\
\hline & & \multirow[b]{2}{*}{$\begin{array}{l}\text { Total } \\
\text { lipid }\end{array}$} & \multicolumn{3}{|c|}{ Chromatographic fractions } \\
\hline & & & $\begin{array}{l}\text { Cholesteryl } \\
\text { ester fraction }\end{array}$ & $\begin{array}{l}\text { Free oleic } \\
\text { acid fraction }\end{array}$ & $\begin{array}{l}\text { All other } \\
\text { fractions }\end{array}$ \\
\hline $\begin{array}{l}\text { Mycoplasma } \\
\text { mycoides var. } \\
\text { capri }\end{array}$ & $7 \cdot 2$ & 11,670 & 120 & 10,800 & 740 \\
\hline $\begin{array}{c}\text { M. laidlawii } \\
\text { oral strain }\end{array}$ & $17 \cdot 6$ & 3,050 & 20 & 430 & 2,600 \\
\hline $\begin{array}{l}\text { M. laidlawii } \\
\text { oral strain* }\end{array}$ & $23 \cdot 0$ & 8,150 & 100 & 2,850 & 5,200 \\
\hline $\begin{array}{r}{\left[\mathrm{U}-{ }^{-14} \mathrm{C}\right]-\text {-oleic }} \\
\text { acid } 0.1 \mu \mathrm{C}\end{array}$ & - & 175,250 & 200 & 172,000 & 3,050 \\
\hline
\end{tabular}

Incorporation of $\left[U^{14} C\right]$-oleic acid into the lipids of Mycoplasma

The saprophytic Mycoplasma laidlawii and the parasitic $M$. mycoides var. capri were tested for ability to incorporate radioactive oleic acid from the growth medium. Table 4 shows that these organisms incorporated small amounts of the radioactive compound. Radioactivity was not found in the cholesteryl ester fraction, indicating the inability of these strains to esterify cholesterol. A portion of the radioactive oleic acid incorporated by the organism was found at the starting line of the chromatoplates, indicating its presence in polar lipids, probably phospholipids. Omission of Difco-PPLO serum fraction from the growth medium of $M$. laidlawii did not have a significant effect on the incorporation of the radioactive oleic acid (Table 4).

\section{DISCUSSION}

The much lower cholesterol content of saprophytic than parasitic Mycoplasma strains noted previously (Razin et al. 1963) has been confirmed in the present study. The saprophytic mycoplasmas were also found to differ from the parasitic strains in being practically unable to incorporate cholesteryl esters from the growth medium. The saprophytic Mycoplasma laidlawii strains which do not require 
sterols for growth (Razin \& Knight, 1960; Rothblat \& Smith, 1961; Razin \& Cohen, 1963) synthesize appreciable amounts of carotenoids localized in the cell membrane, (Razin et al. 1963; Smith, 1963b). The hydrocarbon structure of the carotenoids bears some resemblance to the structure of cholesterol (Smith, 1963a). It is a reasonable speculation that the carotenoids occupy the same sites in the membranes of the saprophytic mycoplasmas as does cholesterol in the membranes of parasitic strains. The carotenoids may thus interfere with the uptake of cholesterol and its esters by the saprophytic strains (see also Smith, 1963b).

Our experiments with $\left[4-{ }^{14} \mathrm{C}\right]$-cholesterol confirmed previous findings (Smith \& Boughton, 1960; Rodwell, 1963; Tourtellotte et al. 1963) which suggested that the cholesterol found in Mycoplasma lipids originates in the growth medium. Our results show, however, that the incorporated cholesterol does not undergo esterification, glycosidation or any other chemical change. This is in accordance with the results reported by Rodwell (1963) for the incorporation of cholesterol by two Mycoplasma mycoides strains.

The cholesteryl esters found in the lipids of parasitic Mycoplasma are apparently incorporated as such from the growth medium and are not formed de novo by the organisms. The ability of mycoplasmas to incorporate cholesteryl esters is much lower than their ability to incorporate free cholesterol. Thus, in spite of the much higher concentration of cholesteryl esters in the growth medium, the amount of free cholesterol in the lipids of the parasitic Mycoplasma, except Mycoplasma mycoides var. capri, exceeded that of esterified cholesterol (see also Morowitz et al. 1962). The incorporated labelled-cholesteryl oleate was not hydrolysed by any of the Mycoplasma strains tested. Neither could we demonstrate cholesterol esterase activity in washed organisms or their extracts, by using cholesteryl acetate or stearate as substrates (see also Rottem \& Razin, 1964). These results are in accordance with the inability of several sterol-requiring Mycoplasma strains to utilize the acetate, stearate or oleate esters of cholesterol for growth (Edward \& Fitzgerald, 1951).

Smith (1959) described both cholesterol ester-hydrolysing and ester-synthesizing activities in several Mycoplasma strains which require cholesterol for growth. The enzymic formation of a cholesteryl glucoside by several strains capable of glucose utilization was also described (Rothblat \& Smith, 1961). Smith (1963a) suggested that the function of these enzymic activities might be to mediate the transfer of glucose and short-chain fatty acids across the cell membrane. Our results indicate that cholesterol may fulfil its still unknown physiological function without being esterified or modified in any other way.

This investigation forms part of a $\mathrm{Ph} . \mathrm{D}$. thesis to be submitted by M. Argaman to the Hebrew University, Jerusalem. The work was supported in part by the Authority for Research and Development, The Hebrew University, Jerusalem.

\section{REFERENCES}

Avigan, J., Goodman, D. S. \& Steinberg, D. (1963). Thin-layer chromatography of sterols and steroids. J. Lipid Res. 4, 100.

Brown, J. L. \& Johnson, J. H. (1962). Radioassay of lipid compounds separated by thin-layer chromatography. J. Lipid Res. 3, 480. 
Edward, D. G. FF. \& Fitzgerald, W. A. (1951). Cholesterol in the growth of organisms of the pleuropneumonia group. J. gen. Microbiol. 5, 576 .

Edward, D. G. FF. \& Freundt, E. A. (1956). The classification and nomenclature of organisms of the pleuropneumonia group. J. gen. Microbiol. 14, 197.

Folch, J., Lees, M. \& Sloane-Stanley, G. H. (1957). A simple method for the isolation and purification of total lipids from animal tissues. J. biol. Chem. 226, 497.

Morowitz, H. J., Tourtellotte, M. E., Guild, W. R., Castro, E., Woese, C. \& Cleverdon, R. C. (1962). The chemical composition and sub-microscopic morphology of Mycoplasma gallisepticum, avian PPLO 5969. J. molec. Biol, 4, 93.

RAzIN, S. (1962). Nutrition and metabolism of pleuropneumonia-like organisms. In Pleuropneumonia-like organisms (PPLO) mycoplasmataceae. Ed. E. Klieneberger-Nobel. London: Academic Press Inc.

Razin, S. $(1963 a)$. Structure, composition and properties of the PPLO cell envelope. Recent Progress in Microbiology, VIII, p. 526. Ed. by N. E. Gibbons. Toronto: University Press.

Razin, S. (1963b). Osmotic lysis of Mycoplasma. J. gen. Microbiol. 33, 471.

Razin, S., Argaman, M. \& Avigan, J. (1963). Chemical composition of Mycoplasma cells and membranes. J. gen. Microbiol. 33, 477 .

Razin, S. \& Cohen, A. (1963). Nutritional requirements and metabolism of Mycoplasma laidlazii. J. gen. Microbiol. 30, 141.

RAzIN, S. \& KNIGHT, B. C. J. G. (1960). A partially defined medium for the growth of Mycoplasma. J. gen. Microbiol. 22, 492.

RoDwell, A. W. (1963). The steroid growth requirements of Mycoplasma mycoides. J. gen. Microbiol. 32, 91.

Ronwell, A. W. \& Aввот, A. (1961). The function of glycerol, cholesterol and long-chain fatty acids in the nutrition of Mycoplasma mycoides. J. gen. Microbiol. 25, 201.

Rothblat, G. H. \& Smith, P. F. (1961). Nonsaponifiable lipids of representative pleuropneumonia-like organisms. J. Bact. 82, 479.

Rotrem, S. \& Razin, S. (1964). Lipase activity of Mycoplasma. J. gen. Microbiol. 37, 123.

SmrTH, P. F. (1959). Cholesterol esterase activity of pleuropneumonia-like organisms. J. Bact. 77, 682.

Smith, P. F. (1962). Fate of ergosterol and cholestanol in pleuropneumonia-like organisms. J. Bact. 84, 534.

Smiтh, P. F. (1963a). The role of sterols in the growth and physiology of pleuropneumonialike organisms. Recent Progress in Microbiology, VIII, p. 518. Ed. by N. E. Gibbons. Toronto: University Press.

Smiтh, P. F. (1963 b). The carotenoid pigments of Mycoplasma. J. gen. Microbiol. $32,307$.

Smith, P. F. (1964). Relation of sterol structure to function in pleuropneumonia-like organisms. J. Lipid Res. 5, 121.

Smith, P. F. \& Boughton, J. E. (1960). Role of protein and phospholipid in the growth of pleuropneumonia-like organisms. J. Bact. 80, 851 .

Smith, P. F. \& LynN, R. J. (1958). Lipid requirements for growth of pleuropneumonia-like organisms. J. Bact. 76, 264.

Smith, P. F. \& Rothblat, G. H. (1960). Incorporation of cholesterol by pleuropneumonialike organisms. J. Bact. 80, 842.

Tountellotte, M. E., Jensen, R. G., Gander, G. W. \& Monowitz, H. J. (1963). Lipid composition and synthesis in the pleuropneumonia-like organism Mycoplasma gallisepticum. J. Bact. 86, 370.

Wycoff, H. D. \& Parsons, J. (1957). Chromatographic microassay for cholesterol and cholesterol esters. Science, 125, 347. 